Received: July 29, 2017

Revision received: January 21, 2018

\title{
Computer-Aided Cognitive Training Based on Electroencephalography-Neurofeedback for English Learning*
}

Liangji $\mathrm{Hu}^{1}$

Central South University
Yajun $\mathrm{Xie}^{2}$

Hunan University of Commerce
Gengxin $\operatorname{Sun}^{3}$

Qingdao University

\begin{abstract}
This paper aims to disclose the effect of cognitive training on English learning. For this purpose, the author reviews the existing computer-aided cognitive-training programs, and developed a targeted cognitive-training approach based on electroencephalography (EEG)-neurofeedback (NFB). Then the approach was applied to a randomized controlled test on the cognition and perception of English learners. The experimental results show that the participants in the test group witnessed significant progress in English learning skills and communicative competence, and post-NFB alpha magnitude could increase independent of NFB conditions. The research findings provide new insights into the application of cognitive training based on NFB-EEG.
\end{abstract}

\section{Keywords}

Neurofeedback $(\mathrm{NFB}) \bullet$ Cognitive Training $\bullet$ Electroencephalography (EEG) $\bullet$ English learning

\footnotetext{
*This research work was financially supported by Hunan Philosophy and Social Science Foundation (Grant No. 11YBA323), and Teaching Reformation Foundation of Central South University (Grant No. 2016JY59). The financially support is highly appreciated.

${ }^{1}$ Correspondence to: Liangi Hu (MA), School of Foreign Languages, Central South University, Changsha 410083, China. Email: prettyrebecca@126.com

${ }^{2}$ School of Foreign Languages, Hunan University of Commerce, Changsha 410205, China. Email: shieyajun2008@163.com ${ }^{3}$ College of Software Engineering, Qingdao University, Qingdao 266071, China. Email: sungengxin @ qdu.edu.cn

Citation: Hu, L. J., Xie, Y. J. \& Sun, G. X. (2018). Computer-Aided Cognitive Training Based on Electroencephalography-Neurofeedback for English Learning. Educational Sciences: Theory \& Practice, 18(5), 25932601. http://dx.doi.org/10.12738/estp.2018.5.002
} 
As is known to all, people differ greatly in how much information they can maintain, manipulate, and transform in their brains all at once. These differences directly exert influence on such outcomes as abstract reasoning, academic performance, and the acquisition of new skills. Most English learners pursue their communicative competence in English learning: the ability to communicate with other English speakers in various fields, including but not limited to, business, tourism, politics and academics. However, there are many difficulties in learning English. In cognitive theory, English learning is viewed as a conscious and reasoned thinking process, involving the deliberate use of learning strategies, i.e. special ways of processing information that enhance information comprehension, learning or retention. This thinking process can be trained through brain activities under special strategies. The most consistent finding in the existing research is that working memory training programs can reliably improve the short-term memory skills (Ball, Berch \& Helmers, 2002; Willis, Tennstedt \& Marsiske., 2006; Ngandu, Lehtisalo \& Solomon, 2015).

Cognitive training aims to maintain and even improve the cognitive abilities by training the brain, similar to the way body fitness is improved by physical exercises (Simons et al., 2016). The training reflects the hypothesis that regular performance of certain activities helps maintain or improve cognitive reserve, that is, the ability to meet the various cognitive demands of life. The cognitive reserve is evident in an ability to assimilate information, comprehend relationships, and develop reasonable conclusions and plans (Scarmeas \& Stern, 2003). Despite the strong evidence on the plasticity of the brain throughout life and the association between high levels of mental activity and reduced risks of agerelated dementia, scientific support for the concept of brain fitness is still limited (Soveri, Antfolk \& Karlsson, 2017). So far, there has been some evidence that some cognitive training programs can improve performance on tasks in which task executors were trained, less evidence that improvements in performance generalize to other related tasks, and almost no evidence that brain training generalizes to every day cognitive performance (Rizos et al., 2010).

One of the most popular cognitive training technologies is neurofeedback (NFB) (Zoefel, Huster \& Herrmann, 2011). The NFB is a type of biofeedback that promotes the self-regulation of brain, using electroencephalography (EEG) to display real-time brain activities (Vernon et al., 2003). It enables the brain to function more efficiently and the participants to control their electroencephalography (EEG) activity. The NFB is generally applied based on EEG activity. It is widely agreed that the NFB is suitable for training those involved in some cognitive task. As a part of mental process, such a task blesses the participant with the behaviour and ability to perceive and acquire knowledge.

Cognitive linguistics, an interdisciplinary branch of cognitive science, is closely related to cognitive psychology and linguistics (Tomasello, 2000). It treats language as a kind of cognitive action, and cognition as departure of language learning and acquisition (Louwerse, 2001). In short, cognitive linguistics is a discipline based on our experience of the world and the way we perceive and conceptualize it (Verdonk et al., 2005). In spite of the long research history of cognitive linguistics, the relationship between cognition and language acquisition is still unclear. To make up for the gap, this paper explores English learning process from the perspective of NFB-based cognitive training.

\section{Methodology}

\section{Computer-Aided Cognitive Training}

Recent years have seen the integration of advanced technologies in cognitive linguistics. Computer assistance is now commonplace in cognitive training. Table 1 lists some of the typical computer-aided cognitive training programs. 
Table 1

Typical Computer-aided Cognitive Training Programs

\begin{tabular}{|c|c|c|c|c|}
\hline Scholars & Design & Computer program & Sample & Outcomes \\
\hline $\begin{array}{l}\text { Plohmann et } \\
\text { al., }\end{array}$ & $\begin{array}{l}\text { 2-group quasi- } \\
\text { experiment }\end{array}$ & $\begin{array}{l}\text { Four } 45 \sim 60 \mathrm{~min} \\
\text { sessions per week for } 4 \\
\text { weeks }\end{array}$ & $\mathrm{N}=10$ & Limited improvement \\
\hline $\begin{array}{l}\text { Mendozzi et } \\
\text { al., }\end{array}$ & $\begin{array}{l}\text { 3-group quasi- } \\
\text { experiment }\end{array}$ & $\begin{array}{l}\text { Fifteen } 45 \text { min sessions } \\
\text { in } 8 \text { weeks; } 2 \text { sessions } \\
\text { per week. }\end{array}$ & $\begin{array}{l}\text { Test group }(n=20) ; \\
\text { Control group } \\
(n=20)\end{array}$ & $\begin{array}{l}\text { Test group has made } \\
\text { greater progress in } \\
\text { memory than the } \\
\text { control group. }\end{array}$ \\
\hline $\begin{array}{l}\text { Birnboim et } \\
\text { al., }\end{array}$ & $\begin{array}{l}\text { 1-group pre- } \\
\text { experiment }\end{array}$ & $\begin{array}{l}\text { Computer-based } \\
\text { strategy games; } 1 \text { h per } \\
\text { week for } 6 \text { months }\end{array}$ & $\mathrm{N}=10$ & $\begin{array}{l}\text { Significant progress in } \\
\text { some measures of } \\
\text { attention }\end{array}$ \\
\hline Solari et al., & $\begin{array}{l}\text { Randomized } \\
\text { controlled trial }\end{array}$ & $\begin{array}{l}\text { RehaCom; two } 45 \mathrm{~min} \\
\text { sessions per week for } 8 \\
\text { weeks in a treatment } \\
\text { centre }\end{array}$ & $\begin{array}{l}\text { Test group }(n=40) ; \\
\text { Control group } \\
(n=37)\end{array}$ & $\begin{array}{l}\text { No difference } \\
\text { between the two } \\
\text { groups }\end{array}$ \\
\hline Tesar et al., & $\begin{array}{l}\text { Randomized } \\
\text { controlled trial }\end{array}$ & $\begin{array}{l}\text { RehaCom; twelve } 1 \mathrm{~h} \\
\text { sessions for } 4 \text { weeks }\end{array}$ & $\begin{array}{l}\text { Test group }(n=10) ; \\
\text { Control group } \\
(n=9)\end{array}$ & $\begin{array}{l}\text { Test group has } \\
\text { significant progress in } \\
\text { spatial-constructional } \\
\text { abilities. }\end{array}$ \\
\hline $\begin{array}{l}\text { Hildebrandt } \\
\text { et al., }\end{array}$ & $\begin{array}{l}\text { Randomized } \\
\text { controlled trial }\end{array}$ & $\begin{array}{l}\text { VILAT-G; } 30 \mathrm{~min} \\
\text { home-based computer } \\
\text { training per day for } 6 \\
\text { weeks; at least } 5 \text { days } \\
\text { per week. }\end{array}$ & $\begin{array}{l}\text { Test group }(n=17) ; \\
\text { Control group } \\
(n=25)\end{array}$ & $\begin{array}{l}\text { Test group has } \\
\text { progress in verbal } \\
\text { learning. }\end{array}$ \\
\hline Vogt et al., & $\begin{array}{l}\text { 3-group quasi- } \\
\text { experiment }\end{array}$ & $\begin{array}{l}\text { Brain Stim; } 45 \mathrm{~min} \\
\text { home-based training } \\
\text { sessions per week for } 4 \\
\text { weeks }\end{array}$ & $\begin{array}{l}\text { High-intensity } \\
\text { group }(n=15) ; \\
\text { Low-intensity } \\
\text { group }(n=15) ; \\
\text { Control group } \\
(n=15)\end{array}$ & $\begin{array}{l}\text { Training effects are } \\
\text { independent of } \\
\text { dosage. }\end{array}$ \\
\hline $\begin{array}{l}\text { Mattioli et } \\
\text { al., }\end{array}$ & $\begin{array}{l}\text { 2-group quasi- } \\
\text { experiment }\end{array}$ & $\begin{array}{l}\text { RehaCom; three } 1 \mathrm{~h} \\
\text { sessions per week for } 3 \\
\text { consecutive months }\end{array}$ & $\begin{array}{l}\text { Test group }(n=10) ; \\
\text { Control group } \\
(n=10)\end{array}$ & $\begin{array}{l}\text { Test group has } \\
\text { significant progress in } \\
\text { attention tests. }\end{array}$ \\
\hline Shatil et al., & $\begin{array}{l}\text { 2-group quasi- } \\
\text { experiment }\end{array}$ & $\begin{array}{l}\text { Cogni-Fit Personal } \\
\text { Coach; three home- } \\
\text { based training sessions } \\
\text { per week for } 12 \text { weeks }\end{array}$ & $\begin{array}{l}\text { Test group }(n=59) ; \\
\text { Control group } \\
(n=48)\end{array}$ & $\begin{array}{l}\text { Test group has made } \\
\text { greater progress than } \\
\text { the control group. }\end{array}$ \\
\hline
\end{tabular}

Previous studies have proved the advantages of computer-aided training over other cognitive trainings. First, the computer-aided training can be self-regulated and tailored to specific needs; Second, the computer programs can provide immediate feedbacks on the results, which are not necessarily clear to the participants. In light of these, this study examines the feasibility of computer-aided cognitive training, and applies a computer program in a randomized controlled trial on the effect of English learners' cognition and perception.

\section{Experimental Design}

For each participant, the experiment contains 35 sessions on the weekdays, one session per day, in seven consecutive weeks. The participants were divided into two groups without difference in age or gender. One group received NFB training (the test group), while the other did not (the control group). During the training, the participants were seated in comfortable chairs in a quiet room. Then, an EEG-NFB-based computer-aided cognitive training system was designed for pre- and post-training EEG measurement. The system consists of a 128-channel electrode cap (as per the Extended International 10/20 System of Electrode Placement), an 
amplifier and a measurement software platform. The EEG frequency bandpass was set to $0.05 \sim 100 \mathrm{~Hz}$. There were two tasks during the pre- and post-training EEG measurement, namely the n-back task and oddball task. In each training session, the n-back task contains three $5 \mathrm{~min}$ independent blocks and $1 \mathrm{~min}$ practice before each block. During each block, the participants were asked to react to the letter flashing on the monitor.

\section{Participants}

Twelve students were recruited from a university in China and randomly divided into the two groups. All of them aged between 20 and 22. Two participants were excluded from subsequent statistical analyses, because the scores of the second cognitive performance assessment fell out of the $95 \%$ confidence interval. The final sample encompasses 5 participants in the test group ( 2 males and 3 females), and 5 in the control group ( 4 males and 1 female).

\section{EEG Measurement}

During the experiment, the EEG was measured with electrodes placed in an elastic cap according to the International 10-20 system. $\mathrm{P} 3, \mathrm{Pz}, \mathrm{P} 4, \mathrm{O} 1$ and $\mathrm{O} 2$ were employed to achieve the same conditions as in normative data. The amplifier bandwidth was set to $0.5 \sim 30 \mathrm{~Hz}$.

An expert electroencephalographer was invited to read out the EEG signals from the measured EEG and further processed them through visual editing for quantitative analysis. In our study, the NFB was administered at electrode Pz with a BioGraph, which recorded the base rates for offline statistical analyses.

\section{NFB Training}

There are four frequency bands of EEG: delta $(0.5 \sim 3.5 \mathrm{~Hz})$, theta $(3.6 \sim 7.5 \mathrm{~Hz})$, alpha $(7.6 \sim 12.5 \mathrm{~Hz})$ and beta $(12.6 \sim 19 \mathrm{~Hz})$. The absolute value (AP) was obtained for each of these frequency bands.

In the cognitive training, the theta and alpha bands of EEG were used. Let $Z$ be the theta-alpha ratio:

$$
Z=(\log (\text { theta } \mathrm{AP} / \text { alpha } \mathrm{AP})-\mu) / \sigma
$$

where $\mu$ and $\sigma$ are the mean value and the standard deviation of the normative sample of the participants, respectively.

Two EEG measurements were made by each student to identify the one with the most abnormal $\mathrm{Z}$ value. Based on EEG activity, the NFB training was performed on the group of the student. Then, the threshold was selected every $2 \mathrm{~min}$, such that the student received the reward between $70 \%$ and $80 \%$ of the time. The ratio was computed every 10 milliseconds and compared with the threshold through the measurement.

\section{Statistical Analysis}

The EEG data were analysed by Fast Fourier Transform (FFT), and computed by bandpass of 5 15Hz. The pre-training analysis results of the two groups are listed in Tables 2 and 3, respectively.

Table 2

\begin{tabular}{ccccc}
\multicolumn{6}{l}{ The Analysis Result of the Test Group } \\
\hline Serial No. & Age & Pre-training score & Post-training score & Gender \\
\hline 1 & 21 & 50 & 72 & $\mathrm{~F}$ \\
2 & 21 & 57 & 67 & $\mathrm{M}$ \\
3 & 20 & 61 & 69 & $\mathrm{~F}$ \\
4 & 20 & 52 & 66 & $\mathrm{~F}$ \\
5 & 22 & 47 & 62 & $\mathrm{M}$ \\
\hline
\end{tabular}

Comparing the pre- and post-training scores, it can be seen that the test group had made greater progress than the control group. 
The mean value and standard deviation of scores before and after training in both groups are shown in Table 4.

The NFB effect on EEG parameters are presented in Table 5.

Table 3

The Analysis Result of the Control Group

\begin{tabular}{ccccc}
\hline Serial No. & Age & Pre-training score & Post-training score & Gender \\
\hline 1 & 22 & 46 & 49 & $\mathrm{M}$ \\
2 & 20 & 51 & 52 & $\mathrm{M}$ \\
3 & 22 & 62 & 64 & $\mathrm{~F}$ \\
4 & 21 & 57 & 58 & $\mathrm{M}$ \\
5 & 20 & 41 & 45 & $\mathrm{M}$ \\
\hline
\end{tabular}

Table 4

Pre- and Post-training Scores

\begin{tabular}{lcccc}
\hline & \multicolumn{2}{c}{ Test group } & \multicolumn{2}{c}{ Control group } \\
\hline & Pre-training & Post-training & Pre-training & Post-training \\
\cline { 2 - 5 } Performance score & $71.2 \pm 12.98$ & $82.6 \pm 13.96$ & $71.4 \pm 11.64$ & $73.6 \pm 2.77$ \\
Verbal score & $85.2 \pm 13.86$ & $91.6 \pm 15.06$ & $86.1 \pm 13.96$ & $85.0 \pm 11.26$ \\
\hline
\end{tabular}

Table 5

NFB Effect on EEG Parameters

\begin{tabular}{|c|c|c|c|c|c|}
\hline \multirow[b]{2}{*}{$\begin{array}{l}\text { EEG } \\
\text { parameter }\end{array}$} & \multirow[b]{2}{*}{$\begin{array}{l}\text { Frequency } \\
\text { band }\end{array}$} & \multicolumn{2}{|c|}{ Pre-training > Post-training } & \multicolumn{2}{|c|}{ Post-training $>$ Pre-training } \\
\hline & & $\begin{array}{l}\text { Global } \\
\text { Prob. }\end{array}$ & Leads $\mathrm{p}<0.05$ & $\begin{array}{l}\text { Global } \\
\text { Prob. }\end{array}$ & Leads $\mathrm{p}<0.05$ \\
\hline \multirow{4}{*}{ Absolute Power } & Delta & $0.03^{*}$ & $\begin{array}{c}\text { Fpl, Fp2, F3, F4, C3, } \\
\text { C4, P3, P4, F8, T4, T6, } \\
\text { Fz, Cz, Pz }\end{array}$ & 0.96 & \\
\hline & Theta & $0.03^{*}$ & $\begin{array}{c}\text { Fp1, Fp2, F3, F4, C3, C4, } \\
\text { P3, F7, F8, T4, T5, T6, } \\
\text { Fz, Cz, Pz }\end{array}$ & 0.90 & \\
\hline & Alpha & $0.03^{*}$ & $\mathrm{P} 4, \mathrm{~T} 4$ & 0.65 & \\
\hline & Beta & $0.01^{*}$ & $\begin{array}{c}\text { Fp1, Fp2, F3, F4, P4, F7, } \\
\text { F8, T4, Fz }\end{array}$ & 0.97 & \\
\hline \multirow{4}{*}{ Relative Power } & Delta & 0.1 & C3, O1, T3, T5 & 0.94 & \multirow{4}{*}{ T6 } \\
\hline & Theta & 0.17 & T6 & 0.65 & \\
\hline & Alpha & 0.91 & & 0.11 & \\
\hline & Beta & 0.59 & & 0.21 & \\
\hline $\begin{array}{l}\text { (AP theta/AP alpha) } \\
\text { ratio }\end{array}$ & & 0.16 & & & 0.92 \\
\hline \multicolumn{6}{|l|}{ Control group } \\
\hline \multirow{4}{*}{ Absolute Power } & Delta & 0.15 & $\mathrm{~F} 4, \mathrm{C} 3, \mathrm{O} 1, \mathrm{O} 2$ & 0.96 & \\
\hline & Theta & 0.09 & O1, T6 & 0.86 & \\
\hline & Alpha & 0.29 & T5 & 0.63 & \\
\hline & Beta & 0.012 & O1, T5 & 0.51 & \multirow{6}{*}{ T6 } \\
\hline \multirow{4}{*}{ Relative Power } & Delta & $0.03^{*}$ & Fp1, Fp2 & 0.77 & \\
\hline & Theta & 0.10 & T6 & 0.29 & \\
\hline & Alpha & 0.62 & & 0.31 & \\
\hline & Beta & 0.95 & & 0.11 & \\
\hline $\begin{array}{l}\text { (AP theta/AP } \\
\text { alpha) ratio }\end{array}$ & & 0.28 & $\mathrm{Cz}$ & 0.77 & \\
\hline
\end{tabular}

Note. $*$ "Leads $\mathrm{p}<0.05$ " means the corresponding places indicating major differences 


\section{Results}

\section{NFB Performance}

According to the trend lines in Figure 1, all test group participants increased their peak alpha frequency through the training.

Figure 1 shows the normalized percent-time above the training threshold. After cognitive training, there was no overall improvement for either group. In most sessions, however, all participants of the test group witnessed an increase in performance, while those in the control group exhibited the exactly opposite trend.

The average change of the test group and control group in different cognitive domains after the NFB training are recorded in Table 6.

According to the general trends of cognitive performance in Table 6, the participants of the test group made greater progress than their control group counterparts in English learning through the NFB-based cognitive training. Comparing the pre- and post- NFB performances, it is safe to say that the cognitive training enhanced the speed and accuracy of English skills.

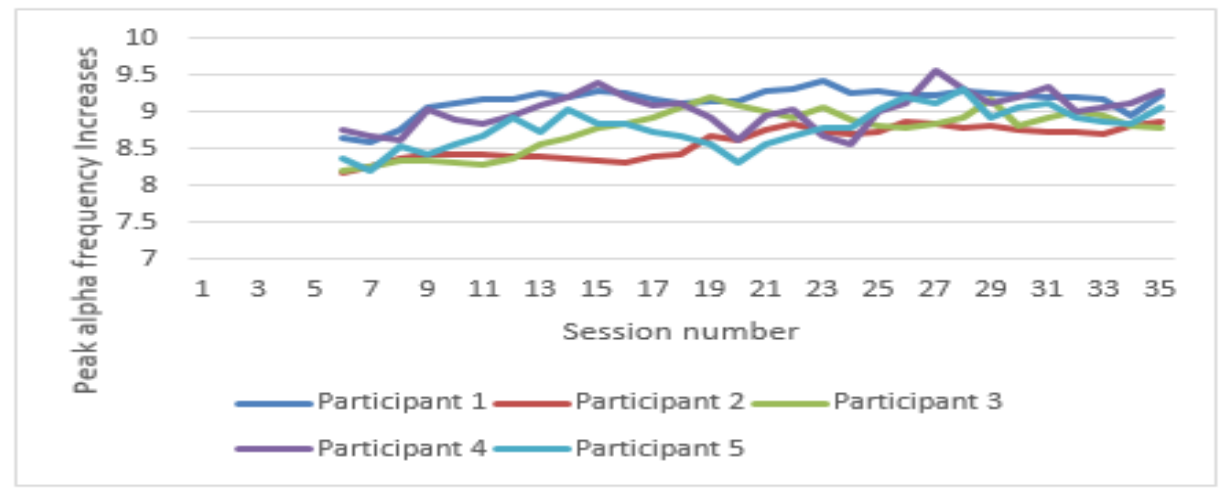

Figure 1. Variation in peak alpha frequency across sessions for all participants

Table 6

Credibility analysis of the scale

\begin{tabular}{lcc}
\hline Item & Test group & Control group \\
\hline Reading & & - \\
Reading speed & + & + \\
Reaction time & + & - \\
Self-reported thinking speed & + & + \\
Syllable accuracy & + & \\
Spelling & & - \\
Spelling speed & + & + \\
Spelling accuracy & + & \\
Writing & & - \\
Writing ability & + & - \\
Writing skills & + & + \\
Writing speed & + & - \\
Listening & & - \\
Listening accuracy & + & \\
Listening speed & + & \\
\hline
\end{tabular}




\section{EEG Results}

After the NFB cognitive training, two participants of the test group and two of the control group saw an increase in their alpha magnitude. Meanwhile, one participant of the test group witnessed no change to her alpha magnitude through the training, and one participant of the control group experienced a decrease in her alpha magnitude

During the experiment, the peak alpha frequency could be obtained from the frontal and posterior areas of the brain. The pattern of peak alpha frequency results is displayed in Figure 2.

As shown in Figure 2, the peak alpha frequency of the test group occurred in the frontal areas. Although the increase is not unexpected, it was expected to appear in the posterior areas instead. The results suggest that the training increased the peak alpha frequency in the frontal areas.
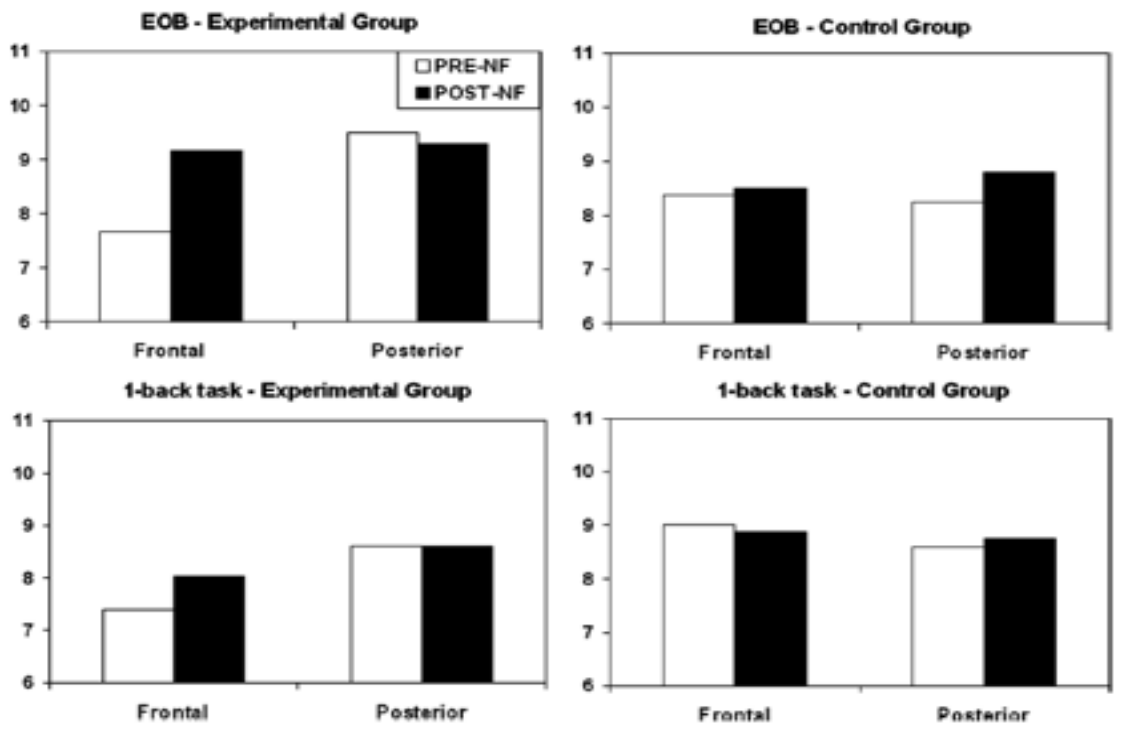

Figure 2. Pre- and post-training peak alpha frequencies Experimental group

\section{Discussion}

\section{NFB Effectiveness}

This study examines the effects of a new NFB training system on the cognitive performance of English learners. Unlike the existing training plans, our cognitive training focuses on changing the peak frequency by computer-aided system, rather than altering the EEG amplitude.

Both the test group and the control group made progress in English learning through the NFB training. Thus, the NFB training system, which focuses on peak alpha frequency, applies to cognitive enhancement, especially for English learning. Although previous studies have repeatedly shown changes specific to the employed NFB training (Costa, Gadea \& Hidalgo 2017; Habibollahi, Souri \&Arbabi, 2016; Egner, Strawson \& Gruzelier, 2002), our research managed to control all possible non-specific factors of NFB training, leaving only frequency-specific EEG effects on cognition. 
Moreover, the experimenter's bias was controlled in our research, because the pre- and post- training cognitive performance can be assessed by experimenters. In recent years, Mikicin, (2015) similarly proved the specificity of EEG-NFB frequency on behavioural changes; Kober et al., (2015) disclosed different cognitive influences for participants trained to increase the amplitude of frequencies.

\section{The Relationship between Cognitive Behavioural Changes and EEG Changes}

The experimental analysis shows that the post-NFB alpha magnitude could increase independent of NFB conditions. During the post-training assessment, two test group participants and three control group participants witnessed alpha magnitude increase. It is likely that these participants were anxious during the initial cognitive training, as they were unfamiliar with the training process. In future, a special pre-training session should be introduced to familiarize the participants with the NFB procedure and minimize their anxiety. The cognition improvement in our study agree well with some of the previous studies. For instance, many scholars also discovered the correlation between frontal peak alpha frequency topography and cognition (Angelakis, Lubar \& Stathopoulou, 2004; Grandy, Markus \& Christian, 2013; Mulik, Nazarv \& Shatyr, 2017).

\section{Conclusion}

The EEG-based NFB training is a promising method for promotion of English learning competence. Many English teachers may be aware of the importance of cognitive training. However, few of them have carried out systematic cognitive training on their students. To solve the problem, this paper sets up a computer-aided NFB cognitive training system based on EEG and applies it to randomized controlled cognitive training of English learners. Through the experiment, the test group showed significant progress in English learning skills. The data analysis shows that the EEG-NFB-based cognitive training may produce varied effects depending on the frequency and modality of training. However, the variation was not observed in our study due to the small sample size. In the future research, the EEG-NFB-based training system will be further verified with a larger sample.

\section{References}

Angelakis, E., Lubar, J. F., \& Stathopoulou, S. (2004). Electroencephalographic peak alpha frequency correlates of cognitive traits. Neuroscience Letters, 371(1), 60-63. http://dx.doi.org/10.1016/j.neulet.2004.08.041

Ball, K., Berch, D. B., \& Helmers, K. F. (2002). Effects of cognitive training interventions with older adults: A randomized controlled trial. Jama, 288(18), 2271-81. http://dx.doi.org/10.1001/jama.288.18.2271

Costa, M. A., Gadea, M., \& Hidalgo, V. (2017). An effective Neurofeedback training, with cortisol correlates, in a clinical case of anxiety. Universitas Psychologica, 15(5), 1-10.

Egner, T., Strawson, E., \& Gruzelier, J. H. (2002). EEG signature and phenomenology of alpha/theta neurofeedback training versus mock feedback. Applied Psychophysiology \& Biofeedback, 27(4), 261-270. http://dx.doi.org/10.1023/A:1021063416558

Grandy, T. H., Markus, W. B., \& Christian, C. (2013). Individual alpha peak frequency is related to latent factors of general cognitive abilities. Neuroimage, 79(79), 10-18.

http://dx.doi.org/10.1016/j.neuroimage.2013.04.059

Habibollahi, S., Souri, A., \& Arbabi, F. (2016). Effects of neurofeedback training on sustain attention and planning in students with attention deficit disorder. Koomesh, 17(2), 447-454.

Kober, S. E., Witte, M., \& Stangl, M. (2015). Shutting down sensorimotor interference unblocks the networks for stimulus processing, an SMR neurofeedback training study. Clinical Neurophysiology Official Journal of the International Federation of Clinical Neurophysiology, 126(1), 82-95.

http://dx.doi.org/10.1016/j.clinph.2014.03.031 
Louwerse, M. (2001). An analytic and cognitive parametrization of coherence relations. Cognitive Linguistics, 12(3), 291-316. http://dx.doi.org/10.1515/cogl.2002.005

Mikicin, M. (2015). The autotelic involvement of attention induced by EEG neurofeedback training improves the performance of an athlete's mind. Biomedical Human Kinetics, 7(1), 58-65.

Mulik, A. B., Nazarov, N. O., \& Shatyr, Y. A. (2017). Electroencephalographic dynamics of individual alpha peak frequency during the female ovarian-menstrual cycle. Human Physiology, 43(4), 488-90.

Ngandu, T., Lehtisalo, J., Solomon, A. (2015). A 2-year multidomain intervention of diet, exercise, cognitive training, and vascular risk monitoring versus control to prevent cognitive decline in at-risk elderly people (FINGER), a randomised controlled trial. The Lancet, 385(9984), 2255-63.

Rizos, E. N., Michalopoulou, P. G., Siafakas, N., Stefanis, N. C., Douzenis, A., Rontos, I., Laskos, E., Kastania, A., Zoumpourlis, V., \& Lykouras, L. (2010). Association of serum brain-derived neurotrophic factor and duration of untreated psychosis in first-episode patients with schizophrenia. Neuropsychobiology, 62(2), 8790. http://dx.doi.org/10.1159/000315438

Scarmeas, N., \& Stern, Y. (2003). Cognitive reserve and lifestyle. Journal of clinical and experimental neuropsychology, 25(5), 625-633. http://dx.doi.org/10.1076/jcen.25.5.625.14576

Simons, D. J., Boot, W. R., Charness, N., Gathercole, S. E., Chabris, C. F., Hambrick, D. Z., Stine-Morrow, E. A. L. (2016). Do "brain-training" programs work?. Psychological Science in the Public Interest, 17(3), 10386. http://dx.doi.org/10.1177/1529100616661983

Soveri, A., Antfolk, J., \& Karlsson, L. (2017). Working memory training revisited, A multi-level meta-analysis of n-back training studies. Psychonomic bulletin \& review, 24(4), 1077-96.

Tomasello, M. (2000). First steps toward a usage-based theory of language acquisition. Cognitive linguistics, 11(1/2), 61-82. http://dx.doi.org/10.1515/cogl.2001.012

Vernon, D., Egner, T., Cooper, N. R., Compton, T., Neilands, C., Sheri, A., \& Gruzelier, J. (2003). The effect of training distinct neurofeedback protocols on aspects of cognitive performance. International Journal of Psychophysiology Official Journal of the International Organization of Psychophysiology, 47(1), 75-85. http://dx.doi.org/10.1016/S0167-8760(02)00091-0

Willis, S. L., Tennstedt, S. L., \& Marsiske, M. (2006). Long-term effects of cognitive training on everyday functional outcomes in older adults. Jama, 296(23), 2805-14. http://dx.doi.org/10.1001/jama.296.23.2805

Zoefel, B., Huster, R. J., \& Herrmann, C. S. (2011). Neurofeedback training of the upper alpha frequency band in EEG improves cognitive performance. Neuroimage, 54(2), 1427-31.

http://dx.doi.org/10.1016/j.neuroimage.2010.08.078 